\title{
Protein dysregulation in graft versus host disease
}

Review

\author{
Liren Qian', Delia Dima², Cristian Berce ${ }^{3}$, Yu Liu ${ }^{1}$, Ioana Rus ${ }^{3}$, Lajos-Zsolt Raduly², \\ Yi Liu ${ }^{1}$, Bobe Petrushev ${ }^{3}$, Ioana Berindan-Neagoe ${ }^{3}$, Alexandru Irimie ${ }^{3}$, Alina \\ Tanase $^{4}$, Ancuta Jurj $^{3}$, Jianliang Shen ${ }^{1}$ and Ciprian Tomuleasa ${ }^{2,3}$ \\ ${ }^{1}$ Department of Hematology, Navy General Hospital, Beijing, PR China \\ ${ }^{2}$ Department of Hematology, Ion Chiricuta Oncology Institute, Cluj Napoca, Romania \\ ${ }^{3}$ Iuliu Hatieganu University of Medicine and Pharmacy, Cluj Napoca, Romania \\ ${ }^{4}$ Department of Stem Cell Transplantation, Fundeni Clinical Institute, Bucharest, Romania \\ Correspondence to: Ciprian Tomuleasa, email: Ciprian.Tomuleasa@umfcluj.ro \\ Liren Qian, email: qlr2007@126.com \\ Keywords: allogeneic stem cell transplantation; biomarkers; proteins; graft versus host disease; exosomes \\ Received: September 28, $2017 \quad$ Accepted: December 05, $2017 \quad$ Published: December 15, 2017 \\ Copyright: Qian et al. This is an open-access article distributed under the terms of the Creative Commons Attribution License 3.0 \\ (CC BY 3.0), which permits unrestricted use, distribution, and reproduction in any medium, provided the original author and source \\ are credited.
}

\section{ABSTRACT}

Allogeneic hematopoietic stem cell transplantation is a well-established treatment for many malignant and non-malignant hematological disorders. As a frequent complication in up to $\mathbf{5 0 \%}$ of all patients, graft-versus-host disease is still the main cause for morbidity and non-relapse mortality. Diagnosis is usually done clinically, even though confirmation by pathology is often used to support the clinical findings. Effective treatment requires intensified immunosuppression as early as possible. Although several promising biomarkers have been proposed for an early diagnosis, no internationally-recognized consensus has yet been established. Proteinbased biomarkers represent an interesting tool since they have been recently reported to be an important regulator of various cells, including immune cells such as $\mathrm{T}$ cells. Therefore, we assume that protein dysregulation is important in the pathogenesis of acute graft versus host disease and their detection might be an possibility in the early diagnosis and monitoring. In this review, we aim to summarize the previous reports of protein biomarkers, focusing on the pathogenesis of the disease and possible implications in diagnostic approaches.

\section{INDICATIONS FOR STEM CELL TRANSPLANTATION}

Hematopoietic stem cell transplantation (HCT) is an efficient immunotherapy for blood malignancies. HCT relies on exploiting the graft versus leukemia (GVL) effects of allogeneic cells [1-3]. Allogeneic HCT (alloHCT) is commonly used for acute myeloid leukemia (AML), with $30 \%$ of allo-HCTs are used in patients with AML, $15 \%$ in patients with acute lymphoblastic leukemia (ALL), 15\% in patients with myelodysplastic syndromes and $10 \%$ in patients with non-Hodgkin's lymphomas [4, 5]. The rest $30 \%$ of allo-HCTs are carried out for patients with chronic lymphocytic leukemias (CLL), plasma cell disorders, hemoglobinopathies, thalassemia, primary immunodeficiency and autoimmune diseases [6, 7]. Disease stage at the time transplantation is performed is of key importance because of relapse risks, as well as toxicity concerns and its main complication: acute graft-versus-host disease (GVHD) (Figure 1). For acute leukemias, HCT is carried out after the first or second complete remission and for lymphoid malignancies, allogeneic SCT is a viable option after the failure of several chemotherapy lines. In the case of myelodysplastic syndromes, therapeutic guidelines are in favor of waiting for disease progression until the phase of blast excess before transplantation is done in order to achieve a higher survival rate [8-10]. 
For a HCT, the selection of the donor is maybe the most important aspect of the pre-transplantation procedures and human leukocyte antigen (HLA) compatibility plays a greater role than even in solid organ transplants. All the genes that encode the HLA antigen are situated on chromosome 6 and thus, the probability of a sibling with a HLA identical match is $25 \%$. Still, without a compatible relative, patients make use of unrelated donors, with the International Donor Registry now reaching around 20 million HLA-types donors [11, 12]. Caucasian patients have the best chances of finding a HLA-suitable donor for class I and II loci, estimated at about $60 \%$ [13, 14]. A half-matched donor is certainly an option, but due to the haploidentical transplant, an intensive cell deletion is required. The results are worse than in a matched transplant with a reduced graft-versus-tumor outcome that results in graft rejection, increased infection risks and malignancy relapse [15-17].

Apart from the HLA-typing, the pre-transplant procedures include chemotherapy and total-body irradiation in order to achieve myeloablation and later allow the donor stem cells to restore the patient's immune system and shorten aplasia. Current protocols use reduced-intensity regimens (RIC) that remove myeloablative chemotherapy and still allow the intensity to be high enough to avoid graft rejection. RIC has also improved stem cell transplantation limitations, making this technique available for the ones over 60 or even 70 years, the group that has the higher prevalence of hematological malignancies [18-20].

\section{EXOSOMES AS THE BACKBONE OF INTERCELLULAR COMMUNICATION}

In a malignant tumor, cells can grow without needing the involvement of the surrounding microenvironment for a limited period of time [21-23]. Afterwards, the malignant cells act at the tumor-vascular interface where they orchestrate the recruitment of endothelial, perivascular or inflammatory cells, as well as platelets and clotting factors [24]. This will alter the local vascular homeostasis. The interaction is mediated by various cytokines, growth factors, proteins or even more important, microRNA species. MicroRNAs (miRs) are short, non-coding RNA species that have been proven to activate messenger RNA (mRNA) in normal development and disease [25-28]. MiRs are either released by cells protected from the surrounding environment in a variety of vesicles or are associated in complexes with proteins. The package through which cells communicate with the outside world by using miRs is extremely important and exosomes were the first extracellular vesicles shown to contain microRNAs [29-32].

Membrane release into the extracellular space has been known and described by Black et al some years ago [33], but only recently it has been proven that microvesicles released by cells are indicative to the cell type or its function. These micro-structures are important in cell-cell transfer and communication and are important in physiological and pathological processes, being found in all body fluids and binding only to selected targets [34]. There are various types of such vesicles, based on their different origin, biogenesis and function. Endosomes and lysosomes undergo a physiological process similar to exocytosis and fuse their membranes with the plasma membrane $[35,36]$. This will lead to the expression of the surface of the vesicle of certain receptors that are also found in the endoplasmic reticulum [37].

Based on their size, the major vesicle populations may be exosomes, microvesicles or apoptotic bodies [38]. Extracellular vesicles are depicted as unique "messenger" used in cell-to-cell communication and mediate the trafficking of various molecules that are traditionally regarded as either insoluble or cell-associated. Such molecules include various membranes, cytoplasmic or nuclear proteins, as well as nucleic acids [39]. Various researchers worldwide have isolated RNA from circulating cancer cells [40] or from bodily fluids [41]. If we consider that RNA is easily degraded and has a short half-life if unprotected in serum [42], it is very fair of us to deduce that the majority of the cell-free RNA species is harbored in different exosomes or similar microvesicle fractions. MicroRNAs may also be encapsulated by protein complexes in blood [43, 44].
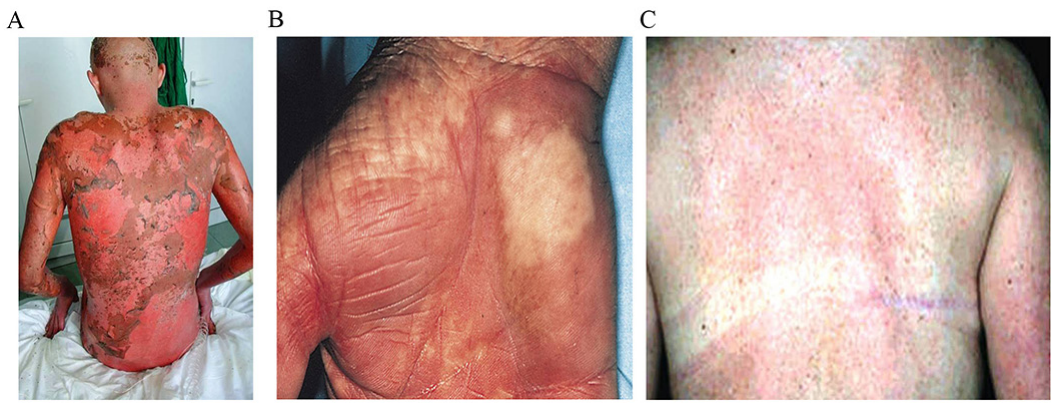

Figure 1: (A) Acute stage IV GVHD, following a myeloablative conditioning chemotherapy. (B) Chronic skin GVHD, following conditioning chemotherapy with TBI and cyclophosphamide. (C) Chronic GVHD, following reduced intensity conditioning chemotherapy. 
As such vesicles are carriers for many molecules between human tissues, they may be considered as potential new sources of biomarkers. Consistent to their physical and immunological characteristics, that include the presence of proteins like Rab GTPases, annexins, flotillin, Alix or Tsg101, as well as integrins or tetraspanins (CD63, CD9, CD81 or CD82), apart from lipids like cholesterol, ceramide or sphingolipids $[45,46]$, we can describe their synthesis. They are generated by reverse budding of the membrane of multivesicular bodies (MVB) [39, 47, 48], that fuse with the plasma membrane previously liberating these particles outside the cell. Then, exosomes enter the vascular or lymphatic system and circulate freely until they bind to their specific target. The release from the cell is possible after the membrane is stimulated by calcium ionophores or phorbol esters. After the synthesis, that can be done in as little time as three hours [49], such structures are released and may either taken by the systemic blood stream, or may remain in the extracellular space near the cell of origin. After being released, they diffuse into bodily fluids such as blood, urine, amniotic fluid, saliva, lung surfactant, malignant effusions, breast milk or even semen. A common exosomes may include hundreds of proteins [30] and influence the fate of other tissues. Examples include annexins and alter the dynamics of the cytoskeleton, Rab GTPases and promote docking and membrane fusion events or endosomal sorting complexes desired for transport [50-52]. In hematopoietic tissues, exosomes express on their surface high MHC class I or II molecules [53-55] and various adhesion molecules like CD146, CD9, EGFRvIII, CD18, CD11a, CD11b, CD11c, CD166 or LFA-3/CD58 [56, 57]. Specific surface markers allow exosomes to be absorbed by distant cells and transfer their proteins, mRNAs, microRNAs, lipids or any other types of molecules, thus forming a particle-based endocrine system.

\section{PROTEIN DYSREGULATION IN HEMATOLOGICAL MALIGNANCIES AND GVHD}

The studies included in the present paper were identified after a search of the National Library of Medicine's MEDLINE database using PubMed and Google Scholar. Candidate papers were limited to English, German, and French language publications, but were not limited to any geographical region, and the most recent search was performed on August 28th, 2017. Only papers published between 1990 and 2017 were considered in order to avoid any inconsistencies in diagnostic criteria and also cover the period of publications on opioid rotation. The search strategy was based on the combination of the keywords "allogeneic stem cell transplantation", "biomarkers", "hematology", "proteomics", and "protein dysregulation". Subsequently, an additional manual search of the citations of the previously selected papers was performed.
GVHD progression is characterized by the differentiation of various alloreactive $\mathrm{T}$ cells into effector cells as a result of the synthesis of additional inflammatory cells and a high cytokine dysregulation $[58,59]$. The same dysregulation caused by GVHD leads to a suppression of the immune system and to tissue damage in various organs such as liver, skin or intestinal mucosa. IL-6 is one of the most important protein-based molecules as it has an inhibitory role over the recognition of the regulatory T-cells after hematopoietic stem cell transplantation. Chen et al [60] have proven this hypothesis by showing that an antibody-linked blockade of the IL-6 receptor serves to recalibrate the effector and regulatory arms of the immune system and represents a novel, potentially clinically translatable, strategy for the attenuation of GVHD. Min et al [61] further expand this study and conclude that a high serum IL-6 level one week post-transplantation may be an early predictor of transplant-related complications and that it seems to trigger pro- and anti-inflammatory cytokine release. Kinetic patterns of IL- 6 and IL-10 were more exaggerated in those with complications after HSCT. The Th2 cytokine IL-10 plays a major inhibitory effect on Th1 cells and their potential in cytokine production, but various studies show that a direct correlation exists between a high level of IL-10 and transplant-related complications. This is linked to balancing the immune system in HSCT. The direct correlation further links a high IL-10 concentration in the serum of transplant patients to the levels of various inflammatory cytokines such as IL-6, IL-1, that can thus be associated with a high grade of hepatic injury, as shown by Yeh et al [62]. Recent data states that IL-15 is another molecule whose expression or dysregulation is linked to the administration of exogenous interleukin-15, of great importance in ontogeny, as well as in the underlying mechanisms of GVHD as a result of their interference with allogeneic T cells. Choi et al [63] stated that an increased level of TNF-alpha is associated with the development of GVHD as high levels of TNF alpha induce the activation of apoptotic cells and produce an allo-antigenic reaction, that is directly linked to the appearance of severe tissue damage via apoptosis and necrosis. The group of Yamamoto et al [64] also correlate the early expression of plasmatic CC-chemokine ligand motif 8 (CCL8) to GVHD and taken together with an involvement of allorecognition in CCL8 expression, it suggests that CCL8 plays an important role in GVHD pathology, but more detailed analysis and further experiments are required to draw a clear conclusion.

Proteins can be used as biomarkers for various diseases, including in hematology and oncology. As GVHD is an immune-mediated disease, that can target organs in the human body, it represents on the most serious clinical problems in allogeneic stem cell transplantation due to its high rate of mortality and morbidity $[65,66]$. For the past few years, physician scientists have tried to develop new therapeutics in order to customize the 
delivery of new immunosuppressive agents as to obtain the optimal results regarding patient care. Such research was focused on the discovery and validation of GVHDrelated essential biomarkers with the main purpose to predict and evaluate the response to therapy, as well as to understand the complex pathophysiology of GVHD. Proteomics is a field with a huge potential impact in the study of GVHD and previously-published papers confirm this hypothesis $[58,67,68]$.

The use of various biomarkers for assessing GVHD, may was investigated by various physicians lately, including Magenau et al $[69,70]$. The optimization of the prevention and therapy of GVHD is most likely to improve the therapeutical outcome of allogeneic stem cell transplantation, with the gradual introduction of a targeted approach in GVHD prophylaxis. This approach is based on translational research, with a special emphasis on the central interaction between antigen presenting cells and $\mathrm{T}$ lymphocytes, with regulatory $\mathrm{T}$ cells maintaining a peripheral tolerance and targeting main transcriptional and signaling pathways of T cells.

Liao et al [71] have proven that IL-2, a molecule that is of key importance in GVHD, influences helper T-cell differentiation by modulating the expression of cytokine receptors in order to help specify and maintain the differentiation status of the immune cells. Cheraï et al [72] have confirmed the results of Liao et al by proving that natural regulatory T-cells are of great therapeutic potential in inducing tolerance in allogeneic cells and organ transplantation. This is achieved as IL-2 influences helper T-cell differentiation by modulating the expression of various cytokine receptors and maintaining the differentiation status of the immune cells. Intrleukin-6 (IL-6) is another molecule of key importance in GVHD as it is correlated with inflammation and maturation of B-cells and acts as a pro-inflammatory cytokine or as an anti-inflammatory cytokine. Massaro et al [73] proved correlated posttransplant death with IL-6, procalcitonin and $\mathrm{C}$ reactive protein (CRP). These results were later confirmed by Pai et al [74] who proved reduced skin GVHD by bortezomib was correlated with reduced serum and skin IL-6 levels. Thus, the administration of a blocking IL-6 antibody in this model also resulted in similar cutaneous GVHD protection. These results indicate that bortezomib or blockade of IL-6 may prevent CD8(+) T cell-mediated cutaneous acute GVHD. Apart from IL-6, IL-8 seems to be important as a biomarker for GVHD, as proven by Pidala et al [75], as well as by Bergen et al [76]. The Italian group has proven that even if the serum cytokine levels were related to several variables associated with HSCT, the two cytokines IL-8 and IL-2R $\alpha$ are predictors of GVHD II-IV and III-IV, translating into a higher treatment-related mortality (TRM) risk ( $17 \%$ vs $3 \%, \mathrm{P}=0.004)$. IL-10 is another protein involved in GVHD pathogenesis, as it is another anti-inflammatory cytokine that down-regulates the expression of the Th1 cytokine, as well as of the major histocompatibility (MHC) class II antigens and their costimulatory molecules in macrophages, just like IL-12hi $[77,78]$.

\section{ROLE OF EXOSOMES IN PROTEIN DYSREGULATION AND GVHD}

One third to almost half of the patients that undergo an allogeneic stem cell transplantation develop either acute or chronic GVHD, out of which most of them are difficult to treat using corticosteroids [79]. Third party mesenchymal stem cells (MSC) have been presented as one possible treatment option for these cases [80], being immunosuppressive and having the ability to prolong the mismatched skin grafts in various mammalian models. Still, new data rather suggest that MSCs have a beneficial effect over the therapy-refractory MSC not because of their direct action, but due to the secretion of various modulating factors [81, 82]. These soluble molecules, of great clinical applications, are secreted ex vivo and are transported in the bodily fluids through small, extracellular vesicles that bud from the plasma membrane. Such vesicles are known as exosomes [83]. The exosomes are released by exocytosis upon fusion of the multivesicular bodies with the plasma membrane and contain lipids, RNA, small non-coding RNAs, as well as proteins [84-90]. All of these factors are transported through the blood stream within exosomes and certainly contribute to inter-cellular communication, thus exerting various immune stimulatory or immune suppressive functions. In a recent paper of the German Cancer Consortium (DKTK - Deutsched Konsortium Translationale Krebsforsching) [91], they used exosomes secreted by mesenchymal stem cells to modulate the immune system and treat chronic GVHD. MSM from four different patients from four different cancer centers of the DKTK, that have underwent a matched unrelated donor (MUD) transplant, the conditioning media was harvested every 48 hours and afterwards the exosomes were isolated. These exosomes were analyzed in order to see whether they have any pro or anti-inflammatory activity, being used as apoptosis-inducing molecules. The exosomes were proven to transport interferon (IFN)- $\gamma$, interleukin (IL)-8, as well as IL-10, transforming growth factor (TGF)-1. Before being tested in patients, the immune modulatory potential was assessed on peripheral blood mononuclear cells (PBMC) and natural killer cells, in mixed lymphocyte reactions. In order to reproduce different allogeneic transplantation settings, HLA class I negative K562 cells, as well as stable HLA-E*01:03 or HLA-B27-transfected K562 variants were used as allogeneic target cells [92]. The MSC-derived exosomes stimulated the PBMC and NKs derived from the patients to secrete IL-1, tumor necrosis factor (TNF)- $\alpha$ and IFN- $\gamma$, proving the immunosuppressive effects of the exosomes and of their protein-based content. The next step 
was to treat chronic GVHD in vivo on a human subject. 0.4$9 \times 10^{\wedge} 6 \mathrm{MSCs}$ are usually used to treat refractory chronic GVHD [93]. Exosomes obtained from 4 x 10^7 MSCs were isolated and calculated as the corresponding dosage for the body weight for the patient and defined as one unit. After four unites were administered, the clinical symptoms of chronic GVHD disappeared and no side effects were detected. Thus, the proteins transported through the blood flow within exosomes have been proven to be efficient in treating GVHD.

Raposo et al have proven that B lymphocytes release major histocompatibility complex (MHC) class II containing exosomes that induce MHC class IIrestricted T lymphocyte responses [94], whereas Zitvogel have shown that dendritic cells release exosomes that carry various functional peptide-bearing $\mathrm{MHC}$ class I and class II molecules [95]. These vesicles promote immunosuppressive responses in mice and have the ability to directly induce the immune responses of CD8+ $\mathrm{T}$ lymphocytes, as well as to activate naïve CD4+ $\mathrm{T}$ lymphocytes in an antigen-specific manner. Exosomes often containing molecules that are associated with various immune suppressive functions, such as Fas ligand, can induce the apoptosis of an activated T cell [96]. Exosomes also mediate the down-regulation of $\mathrm{NKG} 2 \mathrm{D}$ expression on NK cells, as well as CD8+ lymphocytes, which correlates with the functional impairment of both types of lymphocytes [97], with direct implications in transplant immunology, as proven by Pêche et al [98]. They aimed to analyze the effect of the presentation of donor MHC antigens from immature DC-derived exosomes posttransplantation using congenic rats fully mismatched for the class I and II genes of the MHC region. Exosomes were able to significantly prolong graft survival. But the effect was rather moderate. In order to ensure the presentation of allo-antigens, they have used the LF 150195 drug, a new desoxypergualin analog that has recently been reported to prevent DC maturation in vivo $[99,100]$. The combination of donor-derived exosomes with a short-term treatment with the LF 15-0195 had synergistic effects and induced donor-specific allograft tolerance accompanied by prevention or a considerable delay of the appearance of chronic rejection.

If we consider exosomes as the therapeutically active component of a mesenchymal stem cell infusion, the number of clinical applications is comparable to the applications of MSC in transplant medicine. Even more, exosomes are non-self-replicating and because of their small dimensions, may be easily sterilized through filtration. Thus, their clinical potential, both as therapeutics and as diagnostics, is increased.

\section{FUTURE DIRECTIONS}

In many cases, cancer diagnosis is too late or a very efficient treatment because there are no specific biomarkers that might allow doctors to identify a patient with early disease. This is also the case for detecting very early GVHD or disease recurrence or to monitor the tumor's response to chemotherapy. Early detection of all these clinical settings is important to obtain excellent survival rates and current standard-of-care identifies the presence of malignancy after biopsy procurement. This technology is nevertheless sometimes very inaccurate and with important side-effects, highlighting the tremendous importance of minimally invasive management.

Exosomes from different tissues express specific markers on their surface, as presented earlier. These characteristics make them ideal future candidates for biomarkers and a highly efficient management of all diseases, from cancer to chronic inflammatory diseases or infections.

\section{ACKNOWLEDGMENTS}

Ciprian Tomuleasa received funding from the Romanian Research Ministry, contracts PN-II-RUTE-2014-4-1783 (awarded to Young Research Teams) and CNFIS-FDI-2017-1350 (awarded to Institutional development funds), as well as from an international collaboration grant between Romania and P.R. China, contract $57 \mathrm{BM} / 2016$. This paper was funded by Innovative Cultivation Foundation of Chinese Navy General Hospital (Grant No.CXPY201603) and Chinese National key laboratory open subject (Grant No. NKMI2019K01).

\section{CONFLICTS OF INTEREST}

All authors have read and approved the final form of the manuscript and report no potential conflict of interest.

\section{REFERENCES}

1. Gyurkocza B, Rezvani A, Storb RF. Allogeneic hematopoietic cell transplantation: the state of the art. Expert Rev Hematol. 2010; 3:285-299.

2. Kanate AS, Pasquini MC, Hari PN, Hamadani M. Allogeneic hematopoietic cell transplant for acute myeloid leukemia: current state in 2013 and future directions. World J Stem Cells. 2014; 6:69-81.

3. Baron F, Storb R. Allogeneic hematopoietic cell transplantation as treatment for hematological malignancies: a review. Springer Semin Immunopathol. 2004; 26:71-94.

4. Gungor T, Teira P, Slatter M, Stussi G, Stepensky P, Moshous D, Vermont C, Ahmad I, Shaw PJ, Telles da Cunha JM, Schlegel PG, Hough R, Fasth A, et al. Reducedintensity conditioning and HLA-matched haemopoietic stem-cell transplantation in patients with chronic granulomatous disease: a prospective multicentre study. Lancet. 2014; 383:436-448. 
5. Pang N, Xu J, Qu J, Duan X, Yuan H, Chen G, Jiang M, Ding J. Peripheral blood Th9 cells reconstitution and its relationship with acute graft-versus-host disease after matched-sibling peripheral blood hematopoietic stem cell transplantation. Am J Transl Res. 2017; 9:3623-3632.

6. Ferrara F, Schiffer CA. Acute myeloid leukaemia in adults. Lancet. 2013; 381:484-495.

7. Inaba $\mathrm{H}$, Greaves $\mathrm{M}$, Mullighan CG. Acute lymphoblastic leukaemia. Lancet. 2013; 381:1943-1955.

8. Gawade PL, Hudson MM, Kaste SC, Neglia JP, Constine LS, Robison LL, Ness KK. A systematic review of dental late effects in survivors of childhood cancer. Pediatr Blood Cancer. 2014; 61:407-416.

9. Chi AK, Soubani AO, White AC, Miller KB. An update on pulmonary complications of hematopoietic stem cell transplantation. Chest. 2013; 144:1913-1922.

10. Qian L, Wu Z, Shen J. Advances in the treatment of acute graft-versus-host disease. J Cell Mol Med. 2013; 17:966-975.

11. Nowak J. Role of HLA in hematopoietic sct. Bone Marrow Transplant. 2008; 42:S71-S76.

12. Tiercy JM. HLA-C incompatibilities in allogeneic unrelated hematopoietic stem cell transplantation. Front Immunol. 2014; 5:216.

13. Patriarca F, Luznik L, Medeot M, Zecca M, Bacigalupo A, Di Bartolomeo P, Arcese W, Corradini P, Ciceri F, Vago L, Kanakry CG, Fleischhauer K, Martelli MF, et al. Experts' considerations on HLA-haploidentical stem cell transplantation. Eur J Haematol. 2014; 93:187-197.

14. Mayor NP, Robinson J, McWhinnie AJ, Ranade S, Eng K, Midwinter W, Bultitude WP, Chin CS, Bowman B, Marks P, Braund H, Madrigal JA, Latham K, Marsh SG. HLA typing for the next generation. PLoS One. 2015; 10:e0127153.

15. Petersdorf EW. Genetics of graft-versus-host disease: the major histocompatibility complex. Blood Rev. 2013; 27:1-12.

16. Liu H, Stock W, Bishop MR. Expanded indications for allogeneic stem cell transplantation in patients with myeloid malignancies. Curr Opin Hematol. 2013; 20:115-122.

17. Brand A, Doxiadis IN, Roelen DL. On the role of hla antibodies in hematopoietic stem cell transplantation. Tissue A ntigens. 2013; 81:1-11.

18. William BM, de Lima M. Advances in conditioning regimens for older adults undergoing allogeneic stem cell transplantation to treat hematologic malignancies. Drugs Aging. 2013; 30:373-381.

19. Magenau J, Couriel DR. Hematopoietic stem cell transplantation for acute myeloid leukemia: to whom, when, and how. Curr Oncol Rep. 2013; 15:436-444.

20. Wahid SF. Indications and outcomes of reduced-toxicity hematopoietic stem cell transplantation in adult patients with hematological malignancies. Int J Hematol. 2013; 97:581-598.
21. Carmeliet $P$, Baes M. Metabolism and therapeutic angiogenesis. N Engl J Med. 2008; 358:2511-2512.

22. Zerbini G, Lorenzi M, Palini A. Tumor angiogenesis. N Engl J Med. 2008; 359:763; author reply 764.

23. Ribatti D. The involvement of endothelial progenitor cells in tumor angiogenesis. J Cell Mol Med. 2004; 8:294-300.

24. Carmeliet $P$, Jain RK. Molecular mechanisms and clinical applications of angiogenesis. Nature. 2011; 473:298-307.

25. Croce CM, Calin GA. miRNAs, cancer, and stem cell division. Cell. 2005; 122:6-7.

26. Spizzo R, Almeida MI, Colombatti A, Calin GA. Long noncoding RNAs and cancer: a new frontier of translational research? Oncogene. 2012; 31:4577-4587.

27. Calin GA, Cimmino A, Fabbri M, Ferracin M, Wojcik SE, Shimizu M, Taccioli C, Zanesi N, Garzon R, Aqeilan RI, Alder H, Volinia S, Rassenti L, et al. miR-15a and miR-16-1 cluster functions in human leukemia. Proc Natl Acad Sci U S A. 2008; 105:5166-5171.

28. Calin GA, Croce CM. MicroRNAs and chromosomal abnormalities in cancer cells. Oncogene. 2006; 25:6202-6210.

29. Calin GA, Croce CM. MicroRNA signatures in human cancers. Nat Rev Cancer. 2006; 6:857-866.

30. Hata T, Murakami K, Nakatani H, Yamamoto Y, Matsuda $\mathrm{T}$, Aoki N. Isolation of bovine milk-derived microvesicles carrying mRNAs and microRNAs. Biochem Biophys Res Commun. 2010; 396:528-533.

31. Hunter MP, Ismail N, Zhang X, Aguda BD, Lee EJ, Yu L, Xiao T, Schafer J, Lee ML, Schmittgen TD, NanaSinkam SP, Jarjoura D, Marsh CB. Detection of microRNA expression in human peripheral blood microvesicles. PLoS One. 2008; 3:e3694.

32. Pegtel DM, Cosmopoulos K, Thorley-Lawson DA, van Eijndhoven MA, Hopmans ES, Lindenberg JL, de Gruijl TD, Wurdinger T, Middeldorp JM. Functional delivery of viral miRNAs via exosomes. Proc Natl Acad Sci U S A. 2010; 107:6328-6333.

33. Taylor DD, Gercel-Taylor C. MicroRNA signatures of tumor-derived exosomes as diagnostic biomarkers of ovarian cancer. Gynecol Oncol. 2008; 110:13-21.

34. Black PH. Shedding from normal and cancer-cell surfaces. N Engl J Med. 1980; 303:1415-1416.

35. Li L, Masica D, Ishida M, Tomuleasa C, Umegaki S, Kalloo AN, Georgiades C, Singh VK, Khashab M, Amateau S, Li Z, Okolo P, Lennon AM, et al. Human bile contains microRNA-laden extracellular vesicles that can be used for cholangiocarcinoma diagnosis. Hepatology. 2014; 60:896-907.

36. Zaharie F, Muresan MS, Petrushev B, Berce C, Gafencu GA, Selicean S, Jurj A, Cojocneanu-Petric R, Lisencu CI, Pop LA, Pileczki V, Eniu D, Muresan MA, et al. Exosome-carried microRNA-375 inhibits cell progression 
and dissemination via Bcl-2 blocking in colon cancer. $\mathrm{J}$ Gastrointest Liver Dis. 2015; 24:435-443.

37. Pap E, Pallinger E, Pasztoi M, Falus A. Highlights of a new type of intercellular communication: microvesicle-based information transfer. Inflamm Res. 2009; 58:1-8.

38. Del Conde I, Shrimpton CN, Thiagarajan P, Lopez JA. Tissue-factor-bearing microvesicles arise from lipid rafts and fuse with activated platelets to initiate coagulation. Blood. 2005; 106:1604-1611.

39. Thery C, Ostrowski M, Segura E. Membrane vesicles as conveyors of immune responses. Nat Rev Immunol. 2009; 9:581-593.

40. Palazzolo G, Albanese NN, DI Cara G, Gygax D, Vittorelli ML, Pucci-Minafra I. Proteomic analysis of exosome-like vesicles derived from breast cancer cells. Anticancer Res. 2012; 32:847-860.

41. Rak J, Guha A. Extracellular vesicles--vehicles that spread cancer genes. Bioessays. 2012; 34:489-497.

42. Maheswaran S, Haber DA. Circulating tumor cells: a window into cancer biology and metastasis. Curr Opin Genet Dev. 2010; 20:96-99.

43. Schmidt B, Engel E, Carstensen T, Weickmann S, John M, Witt C, Fleischhacker M. Quantification of free RNA in serum and bronchial lavage: a new diagnostic tool in lung cancer detection? Lung Cancer. 2005; 48:145-147.

44. Tsui NB, Ng EK, Lo YM. Stability of endogenous and added RNA in blood specimens, serum, and plasma. Clin Chem. 2002; 48:1647-1653.

45. Thery C, Amigorena S, Raposo G, Clayton A. Isolation and characterization of exosomes from cell culture supernatants and biological fluids. Curr Protoc Cell Biol. 2006; Chapter 3:Unit 322.

46. Sjoqvist C, Snarski E. Inflammatory markers in patients after hematopoietic stem cell transplantation. Arch Immunol Ther Exp (Warsz). 2013; 61:301-307.

47. Mathivanan S, Simpson RJ. Exocarta: a compendium of exosomal proteins and RNA. Proteomics. 2009; 9:4997-5000.

48. Hsu DH, Paz P, Villaflor G, Rivas A, Mehta-Damani A, Angevin E, Zitvogel L, Le Pecq JB. Exosomes as a tumor vaccine: enhancing potency through direct loading of antigenic peptides. J Immunother. 2003; 26:440-450.

49. Yu X, Harris SL, Levine AJ. The regulation of exosome secretion: a novel function of the p53 protein. Cancer Res. 2006; 66:4795-4801.

50. Yu X, Riley T, Levine AJ. The regulation of the endosomal compartment by p53 the tumor suppressor gene. FEBS J. 2009; 276:2201-2212.

51. Thery C, Zitvogel L, Amigorena S. Exosomes: composition, biogenesis and function. Nat Rev Immunol. 2002; 2:569-579.

52. Ostrowski M, Carmo NB, Krumeich S, Fanget I, Raposo G, Savina A, Moita CF, Schauer K, Hume AN, Freitas RP, Goud B, Benaroch P, Hacohen N, et al. Rab27a and Rab27b control different steps of the exosome secretion pathway. Nat Cell Biol. 2010; 12:19-30; suppp 11-13.

53. Pfeffer SR. Two rabs for exosome release. Nat Cell Biol. 2010; 12:3-4.

54. Thery C, Regnault A, Garin J, Wolfers J, Zitvogel L, Ricciardi-Castagnoli P, Raposo G, Amigorena S. Molecular characterization of dendritic cell-derived exosomes. selective accumulation of the heat shock protein hsc73. J Cell Biol. 1999; 147:599-610.

55. Buschow SI, Nolte-'t Hoen EN, van Niel G, Pols MS, ten Broeke T, Lauwen M, Ossendorp F, Melief CJ, Raposo G, Wubbolts R, Wauben MH, Stoorvogel W. MHC II in dendritic cells is targeted to lysosomes or T cell-induced exosomes via distinct multivesicular body pathways. Traffic. 2009; 10:1528-1542.

56. Denzer K, van Eijk M, Kleijmeer MJ, Jakobson E, de Groot C, Geuze HJ. Follicular dendritic cells carry MHC class II-expressing microvesicles at their surface. J Immunol. 2000; 165:1259-1265.

57. Gauvreau ME, Cote MH, Bourgeois-Daigneault MC, Rivard LD, Xiu F, Brunet A, Shaw A, Steimle V, Thibodeau J. Sorting of MHC class II molecules into exosomes through a ubiquitin-independent pathway. Traffic. 2009; 10:1518-1527.

58. Toubai T, Tanaka J, Paczesny S, Shono Y, Reddy P, Imamura M. Role of cytokines in the pathophysiology of acute graft-versus-host disease (GVHD): Are serum/ plasma cytokines potential biomarkers for diagnosis of acute GVHD following allogeneic hematopoietic cell transplantation (Allo-HCT)? Curr Stem Cell Res Ther. 2012; 7:229-239.

59. DiCarlo J, Agarwal-Hashmi R, Shah A, Kim P, Craveiro L, Killen R, Rosenberg-Hasson Y, Maecker H. Cytokine and chemokine patterns across 100 days after hematopoietic stem cell transplantation in children. Biol Blood Marrow Transplant. 2014; 20:361-369.

60. Chen X, Das R, Komorowski R, Beres A, Hessner MJ, Mihara M, Drobyski WR. Blockade of interleukin-6 signaling augments regulatory T-cell reconstitution and attenuates the severity of graft-versus-host disease. Blood. 2009; 114:891-900.

61. Min CK, Lee WY, Min DJ, Lee DG, Kim YJ, Park YH, Kim HJ, Lee S, Kim DW, Lee JW, Min WS, Kim CC. The kinetics of circulating cytokines including IL-6, TNF-alpha, IL-8 and IL-10 following allogeneic hematopoietic stem cell transplantation. Bone Marrow Transplant. 2001; 28:935-940.

62. Yeh SP, Liao YM, Lo WJ, Lin CL, Bai LY, Lin CY, Hsieh CY, Chang YC, Huang YT, Chiu CF. Kinetics of T helper subsets and associated cytokines correlate well with the clinical activity of graft-versus-host disease. PLoS One. 2012; 7:e44416.

63. Choi SW, Levine JE, Ferrara JL. Pathogenesis and management of graft-versus-host disease. Immunol Allergy Clin North Am. 2010; 30:75-101. 
64. Yamamoto M, Ota A, Hori T, Imai S, Sohma H, Suzuki N, Hatakeyama N, Inazawa N, Ito YM, Kimura H, Tsutsumi H, Kokai Y. Early expression of plasma ccl8 closely correlates with survival rate of acute graft-vs.-host disease in mice. Exp Hematol. 2011; 39:1101-1112.

65. Liu X, Yue Z, Yu J, Daguindau E, Kushekhar K, Zhang Q, Ogata Y, Gafken PR, Inamoto Y, Gracon A, Wilkes DS, Hansen JA, Lee SJ, et al. Proteomic characterization reveals that MMP-3 correlates with bronchiolitis obliterans syndrome following allogeneic hematopoietic cell and lung transplantation. Am J Transplant. 2016; 16:2342-2351.

66. Weissinger EM, Mullen W, Albalat A. Urinary proteomics employing capillary electrophoresis coupled to mass spectrometry in the monitoring of patients after stem cell transplantation. Methods Mol Biol. 2014; 1109:293-306.

67. Lochmanova G, Jedlickova L, Potesil D, Tomancova A, Verner J, Pospisilova S, Doubek M, Mayer J, Zdrahal Z. Potential biomarkers for early detection of acute graft-versus-host disease. Proteomics Clin Appl. 2012; 6:351-363.

68. Weissinger EM, Schiffer E, Hertenstein B, Ferrara JL, Holler E, Stadler M, Kolb HJ, Zander A, Zurbig P, Kellmann M, Ganser A. Proteomic patterns predict acute graft-versus-host disease after allogeneic hematopoietic stem cell transplantation. Blood. 2007; 109:5511-5519.

69. Magenau J, Runaas L, Reddy P. Advances in understanding the pathogenesis of graft-versus-host disease. $\mathrm{Br} \mathrm{J}$ Haematol. 2016; 173:190-205.

70. Magenau J, Reddy P. Next generation treatment of acute graft-versus-host disease. Leukemia. 2014; 28:2283-2291.

71. Liao W, Lin JX, Wang L, Li P, Leonard WJ. Modulation of cytokine receptors by IL-2 broadly regulates differentiation into helper T cell lineages. Nat Immunol. 2011; 12:551-559.

72. Cherai M, Hamel Y, Baillou C, Touil S, Guillot-Delost M, Charlotte F, Kossir L, Simonin G, Maury S, Cohen JL, Lemoine FM. Generation of human alloantigen-specific regulatory $\mathrm{T}$ cells under good manufacturing practicecompliant conditions for cell therapy. Cell Transplant. 2015; 24:2527-2540.

73. Massaro KS, Macedo R, de Castro BS, Dulley F, Oliveira MS, Yasuda MA, Levin AS, Costa SF. Risk factor for death in hematopoietic stem cell transplantation: Are biomarkers useful to foresee the prognosis in this population of patients? Infection. 2014; 42:1023-1032.

74. Pai CC, Hsiao HH, Sun K, Chen M, Hagino T, Tellez J, Mall C, Blazar BR, Monjazeb A, Abedi M, Murphy WJ. Therapeutic benefit of bortezomib on acute graft-versushost disease is tissue specific and is associated with interleukin-6 levels. Biol Blood Marrow Transplant. 2014; 20:1899-1904.

75. Pidala J, Sarwal M, Roedder S, Lee SJ. Biologic markers of chronic gvhd. Bone Marrow Transplant. 2014; 49:324-331.

76. Berger M, Signorino E, Muraro M, Quarello P, Biasin E, Nesi F, Vassallo E, Fagioli F. Monitoring of TNFR1,
IL-2Ralpha, HGF, CCL8, IL-8 and IL-12p70 following HSCT and their role as GVHD biomarkers in paediatric patients. Bone Marrow Transplant. 2013; 48:1230-1236.

77. Auletta JJ, Eid SK, Wuttisarnwattana P, Silva I, Metheny L, Keller MD, Guardia-Wolff R, Liu C, Wang F, Bowen T, Lee Z, Solchaga LA, Ganguly S, et al. Human mesenchymal stromal cells attenuate graft-versus-host disease and maintain graft-versus-leukemia activity following experimental allogeneic bone marrow transplantation. Stem Cells. 2015; 33:601-614.

78. Stenger EO, Rosborough BR, Mathews LR, Ma H, Mapara MY, Thomson AW, Turnquist HR. IL-12hi rapamycinconditioned dendritic cells mediate IFN-gamma-dependent apoptosis of alloreactive CD4+ T cells in vitro and reduce lethal graft-versus-host disease. Biol Blood Marrow Transplant. 2014; 20:192-201.

79. Deeg HJ. How i treat refractory acute GVHD. Blood. 2007; 109:4119-4126.

80. Le Blanc K, Rasmusson I, Sundberg B, Gotherstrom C, Hassan M, Uzunel M, Ringden O. Treatment of severe acute graft-versus-host disease with third party haploidentical mesenchymal stem cells. Lancet. 2004; 363:1439-1441.

81. Girdlestone J. Mesenchymal stromal cells with enhanced therapeutic properties. Immunotherapy. 2016; 8:1405-1416.

82. Zhang X, Peng Y, Fan Z, Zhao K, Chen X, Lin R, Sun J, Wang G, Xiang A, Liu Q. Mesenchymal stem cells may ameliorate nephrotic syndrome post-allogeneic hematopoietic stem cell transplantation-case report. Front Immunol. 2017; 8:962.

83. Lai RC, Arslan F, Lee MM, Sze NS, Choo A, Chen TS, Salto-Tellez M, Timmers L, Lee CN, El Oakley RM, Pasterkamp G, de Kleijn DP, Lim SK. Exosome secreted by MSC reduces myocardial ischemia/reperfusion injury. Stem Cell Res. 2010; 4:214-222.

84. Tomuleasa C, Fuji S, Cucuianu A, Kapp M, Pileczki V, Petrushev B, Selicean S, Tanase A, Dima D, BerindanNeagoe I, Irimie A, Einsele H. MicroRNAs as biomarkers for graft-versus-host disease following allogeneic stem cell transplantation. Ann Hematol. 2015; 94:1081-1092.

85. Peng H, Ishida M, Li L, Saito A, Kamiya A, Hamilton JP, Fu R, Olaru AV, An F, Popescu I, Iacob R, Dima S, Alexandrescu ST, et al. Pseudogene INTS6P1 regulates its cognate gene INTS6 through competitive binding of miR-17-5p in hepatocellular carcinoma. Oncotarget. 2015; 6:5666-5677. https://doi.org/10.18632/oncotarget.3290.

86. Braicu C, Tomuleasa C, Monroig P, Cucuianu A, BerindanNeagoe I, Calin GA. Exosomes as divine messengers: are they the hermes of modern molecular oncology? Cell Death Differ. 2015; 22:34-45.

87. Tomuleasa C, Braicu C, Irimie A, Craciun L, BerindanNeagoe I. Nanopharmacology in translational hematology and oncology. Int J Nanomed. 2014; 9:3465-3479.

88. Frinc I, Muresan MS, Zaharie F, Petrov L, Irimie A, Berce C, Berindan-Neagoe I, Tomuleasa C. Cancer stem-like 
cells: the dark knights of clinical hematology and oncology. J BUON. 2014; 19:328-335.

89. Susman S, Tomuleasa C, Fekete Z, Pilato B, Irimie A, Berindan-Neagoe I. The importance of microRNAs in the stroma-breast cancer cell interplay. Cancer Biomark. 2014; 14:137-144.

90. Rani B, Cao Y, Malfettone A, Tomuleasa C, Fabregat I, Giannelli G. Role of the tissue microenvironment as a therapeutic target in hepatocellular carcinoma. World J Gastroenterol. 2014; 20:4128-4140.

91. Kordelas L, Rebmann V, Ludwig AK, Radtke S, Ruesing J, Doeppner TR, Epple M, Horn PA, Beelen DW, Giebel B. MSC-derived exosomes: a novel tool to treat therapyrefractory graft-versus-host disease. Leukemia. 2014; 28:970-973.

92. Ulbrecht M, Martinozzi S, Grzeschik M, Hengel H, Ellwart JW, Pla M, Weiss EH. Cutting edge: the human cytomegalovirus UL40 gene product contains a ligand for HLA-E and prevents NK cell-mediated lysis. J Immunol. 2000; 164:5019-5022.

93. Ringden O, Le Blanc K. Mesenchymal stem cells for treatment of acute and chronic graft-versus-host disease, tissue toxicity and hemorrhages. Best Pract Res Clin Haematol. 2011; 24:65-72.

94. Raposo G, Nijman HW, Stoorvogel W, Liejendekker R, Harding CV, Melief CJ, Geuze HJ. B lymphocytes secrete antigen-presenting vesicles. J Exp Med. 1996; 183:1161-1172.
95. Zitvogel L, Regnault A, Lozier A, Wolfers J, Flament C, Tenza D, Ricciardi-Castagnoli P, Raposo G, Amigorena S. Eradication of established murine tumors using a novel cellfree vaccine: dendritic cell-derived exosomes. Nat Med. 1998; 4:594-600.

96. Kim JW, Wieckowski E, Taylor DD, Reichert TE, Watkins $\mathrm{S}$, Whiteside TL. Fas ligand-positive membranous vesicles isolated from sera of patients with oral cancer induce apoptosis of activated T lymphocytes. Clin Cancer Res. 2005; 11:1010-1020.

97. Clayton A, Mitchell JP, Court J, Linnane S, Mason MD, Tabi Z. Human tumor-derived exosomes down-modulate NKG2D expression. J Immunol. 2008; 180:7249-7258.

98. Peche H, Renaudin K, Beriou G, Merieau E, Amigorena S, Cuturi MC. Induction of tolerance by exosomes and shortterm immunosuppression in a fully MHC-mismatched rat cardiac allograft model. Am J Transplant. 2006; 6:1541-1550.

99. Yang J, Bernier SM, Ichim TE, Li M, Xia X, Zhou D, Huang X, Strejan GH, White DJ, Zhong R, Min WP. LF150195 generates tolerogenic dendritic cells by suppression of NF-kappaB signaling through inhibition of IKK activity. J Leukoc Biol. 2003; 74:438-447.

100. Min WP, Zhou D, Ichim TE, Strejan GH, Xia X, Yang J, Huang X, Garcia B, White D, Dutartre P, Jevnikar AM, Zhong R. Inhibitory feedback loop between tolerogenic dendritic cells and regulatory $\mathrm{T}$ cells in transplant tolerance. J Immunol. 2003; 170:1304-1312. 